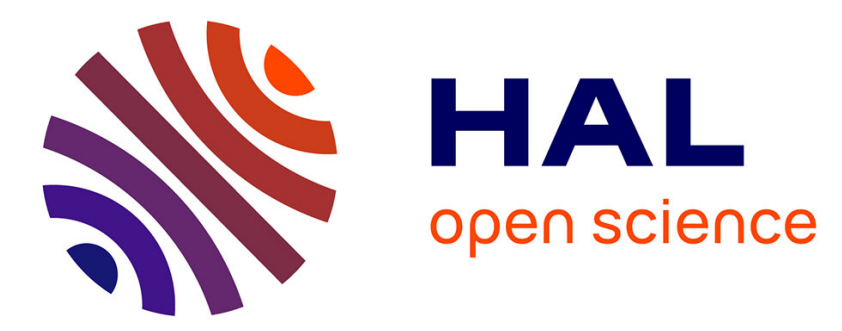

\title{
Overlap in trophic and temporal niches in the flower-visiting bee guild (Hymenoptera, Apoidea) of a tropical dry forest
}

Gilberto M. Santos, Carlos Carvalho, Cândida Aguiar, Leonardo Macêdo, Marco Mello

\section{To cite this version:}

Gilberto M. Santos, Carlos Carvalho, Cândida Aguiar, Leonardo Macêdo, Marco Mello. Overlap in trophic and temporal niches in the flower-visiting bee guild (Hymenoptera, Apoidea) of a tropical dry forest. Apidologie, 2012, 44 (1), pp.64-74. 10.1007/s13592-012-0155-8 . hal-01201271

\section{HAL Id: hal-01201271 \\ https://hal.science/hal-01201271}

Submitted on 17 Sep 2015

HAL is a multi-disciplinary open access archive for the deposit and dissemination of scientific research documents, whether they are published or not. The documents may come from teaching and research institutions in France or abroad, or from public or private research centers.
L'archive ouverte pluridisciplinaire HAL, est destinée au dépôt et à la diffusion de documents scientifiques de niveau recherche, publiés ou non, émanant des établissements d'enseignement et de recherche français ou étrangers, des laboratoires publics ou privés. 


\title{
Overlap in trophic and temporal niches in the flower-visiting bee guild (Hymenoptera, Apoidea) of a tropical dry forest
}

\author{
Gilberto M. de M. Santos ${ }^{1}$, Carlos A. L. de Carvalho ${ }^{2}$, Cândida M. L. Aguiar ${ }^{1}$, \\ Leonardo S. S. R. MACÊDO ${ }^{3}$, Marco A. R. MELlo ${ }^{4}$ \\ ${ }^{1}$ Departamento de Ciências Biológicas, Universidade Estadual de Feira de Santana, 44036-900 Feira de Santana, \\ Bahia, Brazil \\ ${ }^{2}$ Núcleo de Estudo dos Insetos, Centro de Ciências Agrárias, Ambientais e Biológicas, Universidade Federal do \\ Recôncavo da Bahia, 44380-000 Cruz das Almas, Bahia, Brazil \\ ${ }^{3}$ Programa de Pós-Graduação em Zoologia, Universidade Estadual de Feira de Santana, Feira de Santana, Brazil \\ ${ }^{4}$ Institut für Experimentelle Ökologie, Universität Ulm, Albert-Einstein-Allee 11, 89069 Ulm, Germany
}

Received 27 February 2012 - Revised 29 May 2012 - Accepted 19 June 2012

\begin{abstract}
In tropical dry and hot forests, flower-visiting bees are able to forage only during the few hours a day with mild temperatures, but they may chose more freely among the plant species to be visited. Therefore, we tested the hypothesis that the overlap in temporal niches should be higher than the overlap in trophic niches among these bees. Between pairs of species (Schoener index), the overlap in trophic niches varied from 0.007 to 0.745 , whereas the temporal overlap varied from 0.062 to 0.865 . In general, the trophic overlap was low, with $79 \%$ of the species pairs scoring below $30 \%$, and the temporal overlap varied from moderate to high. At the community level, the observed overlap in trophic niches was higher than expected by chance, both for diet and foraging time. The network analysis confirmed at the community level that bees separate more strongly their trophic $(E=0.82)$ than their temporal niches $(E=0.50)$.
\end{abstract}

trophic niche / temporal niche / niche overlap / bee guild / Apoidea

\section{INTRODUCTION}

Many ecological studies aimed at understanding the processes that structure natural communities, and recently, several of them have stressed the importance of species interactions (Bascompte and Jordano 2007; Santos et al. 2010) as well as the role of scarcity of food resources (Vasconcelos et al. 2010) for community structure. Antagonistic and mutualistic interactions seem to be fundamental in this context; they may result in the formation of

Corresponding author: G.M. de M. Santos, gmms.uefs@gmail.com

Manuscipt Editor: Marina Meixner subgroups of species with similar requirements that perform similar functions in the community: the guilds (Root 1967; Blondel 2003). Guilds can be structured in different ways, following two main possibilities: (1) the structure is mediated by competition and, in this case, guilds are expected in sites where resources are limited (Pianka 1980) or (2) the structuration of guilds happens due to convergent use of resources by species with similar ecological requirements (Hairston 1984).

When competition for food among species of the same guild is strong, a temporal segregation in resource use can attenuate competition and so facilitate coexistence (Hölldobler and Wilson 1990). Therefore, activity time is another 
important niche dimension (Pianka 1973). Studies on niche overlap help us understand better the guild structure of a community. There are several approaches to analyze niche overlap (Wilms et al. 1996; Thomson 2006; Behmer and Joern 2008; Presley et al. 2009). Currently, tools from network theory have been used for this task (Bascompte and Jordano 2007; Araújo et al. 2010). Those tools allow us to evaluate niche overlap not only between pairs of species but also in the community as a whole (see Presley et al. 2009; Santos et al. 2010).

In the present study, we assessed the overlap in trophic and temporal niches in the guild of flower-visiting bees in a Caatinga area (tropical dry forest). Since Caatinga areas are characterized by extreme abiotic conditions (e.g., semi-arid climate, with high temperature and low relative air humidity), with high temperature variations throughout the day and a dry season with food shortage for flower visitors, we tested the hypothesis that niche overlap among bee species should be determined by a balance between environmental restrictions and competition for food. We expected (1) that temporal niche overlap among species should be high since in tropical semi-arid environments, such as the Caatinga, there are hours a day when extremely high temperatures may limit bee foraging due to overheating (Willmer and Stone 1997) and (2) that trophic niche overlap should be low since competition should be intensified by the high overlap in temporal niches, leading to segregation of trophic niches, so that species may coexist.

\section{MATERIALS AND METHODS}

Data on bee-plant interactions were collected in Vale do Rio Paraguaçu, municipality of Castro Alves, state of Bahia, northeastern Brazil $\left(12^{\circ} 45^{\prime} \mathrm{S}, 39^{\circ} 26^{\prime}\right.$ W). The study area is covered by open shrubby Caatinga vegetation with sparse trees, where part of the natural vegetation has been replaced by pastures. The regional climate is tropical semi-arid.

In each sampling session, two collectors captured bees visiting flowers with entomological nets along a $2-\mathrm{km}$ trail. The collecting time per specimen of the flowering plant was standardized as 5 min (following Sakagami et al. 1967). The collection of bees and visited plants occurred every 2 weeks, from January 1994 to February 1995. Sampling was carried out from 0500 to 1800 hours, summing up 24 samples, each $13 \mathrm{~h}$ long, or $312 \mathrm{~h}$ of sampling per collector.

Abundance data for each species of flower-visiting bee were used in the niche overlap analysis. For this analysis, all species with total abundance below ten individuals were removed. Overlap degrees of trophic and temporal niches for each pair of bee species were calculated with the Schoener index (1986) using the formula $\mathrm{NO}_{i h}=1-1 / 2 \sum k\left|p_{i k}-p_{h k}\right|$, where $i$ and $h$ represent the pair of species compared and $p_{i k}$ and $p_{h k}$ are the proportion of individuals of the bee species $i$ and $h$ collected in each plant species $k$ in the trophic niche analysis, or in each sampling period $k$ in the temporal niche analysis, respectively. The value of $p_{i k}$ is calculated as the ratio between the number of individuals of the bee species $i$ and the total number of individuals of this bee species collected in all plant species (trophic niche) or during the whole sampling period (temporal niche).

Additionally, we calculated the general overlap degree among all species in the community using the Pianka (1973) and Czechanowski indices (Feinsinger et al. 1981). To test whether the average overlap values found were higher or lower than expected by chance, we used a Monte Carlo approach (Presley et al. 2009). We used the software TimeOverlap and the algorithm Rosario with 10,000 iterations. This algorithm creates randomizations of the original matrix, calculates for each randomized matrix its degree of niche overlap, and then compares the value calculated for the original matrix with the distribution of randomized values. When the value of the real matrix was higher or lower than $95 \%$ of the randomized values (two-tailed test), we considered the degree of niche overlap as significant $(\alpha=0.05)$.

The networks of bee visits to plants and of overlap in activity times were organized as adjacency matrices and represented as bipartite graphs using the package bipartite 1.17 for R (Dormann et al. 2009). The degree of dietary specialization was calculated 
with the $E$ index (Araújo et al. 2008), which varies from 0 (diets of all species are the same) to 1 (each species has a different diet). This index is based on the aggregation coefficient measured in unipartite networks (Costa et al. 2007). To calculate the aggregation coefficient, the original bipartite matrix (i.e., bees and plants) was transformed into a unipartite projection of the bee side, in which the connections are defined by niche overlap (i.e., bees that visit at least one common same plant or bees that forage at the same time), with weights calculated with the Schoener index (Araújo et al. 2008). The significance of $E$ was estimated through a Monte Carlo procedure with 1,000 iterations $(\alpha=0.05)$ in the program Dieta (Araújo et al. 2008).

\section{RESULTS}

Eighty bee species were recorded visiting flowers of 83 native and exotic plant species (Table I). However, the number of bees and the plants visited varied widely from month to month. The number of bees collected monthly ranged from 2 to 38 species between months, while the number of plants visited varied from 4 to 24 species. (Figure 1). Among bees, 34 species were represented by more than ten individuals and, therefore, were included in the analysis. The bees Apis mellifera Linnaeus $(n=1,374)$, Trigona spinipes Fabricius $(n=430)$, and Xylocopa grisescens Lepeletier $(n=140)$ had higher abundance, representing $61 \%$ of the sampled flower visitors. Among plant species, Poincianella pyramidalis (Tul.) L.P. Queiroz $(n=486)$, Portulaca oleracea L. $(n=363)$, and Centratherum punctatum Cass. $(n=209)$ were the most frequently visited and represented $60 \%$ of all visits. The times of highest visit frequency to flowers were 10001100, 0900-1000, and 1400-1500 hours, when 557,426 , and 423 visits were recorded, respectively, summing up $41.15 \%$ of all visits.

We analyzed 561 combinations of pairs of species formed with 34 bee species (Table II). Trophic niche overlap between pairs of bee species $\left(\mathrm{NO}_{i h}\right)$, calculated from visit frequencies, varied from 0.007 to 0.745 ; the highest values were found between Diadasina riparia Ducke and Megachile paulistana Schrottky $\left(\mathrm{NO}_{i h}=\right.$ 0.745 ) and between Xylocopa carbonaria Smith and Xylocopa cearensis Ducke $\left(\mathrm{NO}_{i h}=0.745\right)$, whereas the lowest values were recorded for the pairs Gaesischia hyptidis (Ducke) and X. grisescens $\left(\mathrm{NO}_{i h}=0.007\right)$, and G. hyptidis and Centris aenea Lepeletier $\left(\mathrm{NO}_{i h}=0.007\right.$; Table II).

The temporal overlap between pairs of bee species, inferred from the time of capture of each specimen during its visit to a flower, varied from 0.062 to 0.865 , with higher average values than in the trophic niche overlap (Table III). The highest overlap values were observed between Caenonomada unicalcarata (Ducke) and Melipona asilvai Moure $\left(\mathrm{NO}_{i h}=0.860\right)$ and between Coelioxys simillima Smith and Trigonisca sp. $\left(\mathrm{NO}_{i h}=0.820\right)$. The lowest overlap values were observed between Bombus morio Swederus and Diadasina paraensis (Ducke) $\left(\mathrm{NO}_{i h}=0.062\right)$ and between Exomalopsis auropilosa Spinola and Plebeia sp. $1 \quad\left(\mathrm{NO}_{i h}=0.062\right.$; Table III). In general, trophic overlap was low, with $79 \%$ of the pairs exhibiting values below $30 \%$, whereas temporal overlap varied from moderate to high, with $55 \%$ of the pairs exhibiting values between 30 and $60 \%$.

Trophic niche overlap at the community level (i.e., among all 34 bee species analyzed) was higher than expected by chance, both for diet and foraging time. The average overlap values estimated with the indices of Pianka (diet axis= 0.26; time axis $=0.58$ ) and Czechanowski (diet axis $=0.18$; time axis $=0.49$ ) were significant (both $P<0.001$ ). The network analysis showed similar results as we observed that bees separate their niches more strongly in diet $(E=0.82$, $P<0.001)$ than in foraging time $(E=0.50$, $P<0.001$; Figures 2 and 3).

\section{DISCUSSION/CONCLUSION}

In the present study, we observed that flower-visiting bees in our study area separate more strongly their trophic niches than 
Table I. Bee species and plants visited for floral resources in a Caatinga area in Castro Alves, northeastern Brazil.

\begin{tabular}{|c|c|c|c|}
\hline Bees & Code & Plants & Code \\
\hline Acamptopoeum prinii (Holmberg) ${ }^{\mathrm{a}}$ & B01 & Senegalia bahiensis (Benth.) & $\mathrm{P} 1$ \\
\hline Acamptopoeum vagans $\left(\right.$ Cockerell) ${ }^{\mathrm{a}}$ & B02 & Senegalia langsdorffii (Benth.) & $\mathrm{P} 2$ \\
\hline Apis mellifera Linnaeus & B03 & Acanthaceae sp.1 & P3 \\
\hline Augochlora esox (Vachal) ${ }^{\mathrm{a}}$ & B04 & Adenocalymma coriaceum DC. & P4 \\
\hline Augochlora (Augochlora) sp. ${ }^{a}$ & B05 & Aeschynomene mollicula Kunth & P5 \\
\hline Augochlora (Oxystoglossella) sp. ${ }^{a}$ & B06 & Ageratum conyzoides L. & P6 \\
\hline Augochlorella ephyra (Schrottky) ${ }^{\mathrm{a}}$ & B07 & Albizia polycephala (Kunth) & P7 \\
\hline Augochlorella sp. $1^{\text {a }}$ & B08 & Alternanthera tenella Colla & P8 \\
\hline Augochloropsis callichroa (Cockerell) & B09 & Anadenanthera colubrina (Vell.) & P9 \\
\hline Augochloropsis cockerelli Schrottky ${ }^{\mathrm{a}}$ & $\mathrm{B} 10$ & Astronium cf. macrocalyx Engl. & $\mathrm{P} 10$ \\
\hline Augochloropsis sp. $1^{\mathrm{a}}$ & B11 & Blanchetiodendron blanchetii (Benth.) & P11 \\
\hline Augochloropsis sp. $2^{\mathrm{a}}$ & B12 & Bowdichia virgilioides Kunth & $\mathrm{P} 12$ \\
\hline Augochloropsis terrestris (Vachal) ${ }^{\mathrm{a}}$ & B13 & Sideroxylon obtusifolium (Roemer \& Schultes) & $\mathrm{P} 13$ \\
\hline Bombus pauloensis Friese $^{\mathrm{a}}$ & B14 & Poincianella pyramidalis (Tul.) & P14 \\
\hline Bombus morio (Swederus) & B15 & Capparis yco Mart. & P15 \\
\hline Caenonomada unicalcarata (Ducke) & B16 & Cardiospermum corundum $\mathrm{L}$. & P16 \\
\hline Centris (Centris) sp. $1^{\mathrm{a}}$ & B17 & Centratherum punctatum Cass. & P17 \\
\hline Centris (Centris) sp. $2^{\mathrm{a}}$ & B18 & Centrosema virginianum $\mathrm{L}$. & P18 \\
\hline Centris trigonoides Lepeletier ${ }^{\mathrm{a}}$ & B19 & Cereus jamacaru DC. & P19 \\
\hline Centris (Melacentris) sp. $1^{\mathrm{a}}$ & $\mathrm{B} 20$ & Cissus simsiana Roem. \& Schult. & $\mathrm{P} 20$ \\
\hline Centris (Melacentris) sp. $2^{\mathrm{a}}$ & B21 & Commelina $\mathrm{cf}$. benghalensis L. & $\mathrm{P} 21$ \\
\hline Centris aenea Lepeletier & B22 & Copaifera langsdorffii Desf. & $\mathrm{P} 22$ \\
\hline Centris flavifrons (Fabricius) ${ }^{\mathrm{a}}$ & $\mathrm{B} 23$ & Cordia superba Cham. & $\mathrm{P} 23$ \\
\hline Centris fuscata Lepeletier & B24 & Crataeva tapia $\mathrm{L}$. & $\mathrm{P} 24$ \\
\hline Centris hyptidis Ducke ${ }^{\mathrm{a}}$ & $\mathrm{B} 25$ & Crotalaria incana $\mathrm{L}$. & $\mathrm{P} 25$ \\
\hline Centris decolorata Lepeletier $^{\mathrm{a}}$ & B26 & Croton campestris A. St.-Hil. & $\mathrm{P} 26$ \\
\hline Centris spilopoda Moure $^{\mathrm{a}}$ & B27 & Croton moritibensis Baill. & $\mathrm{P} 27$ \\
\hline Centris tarsata Smith & B28 & Cuphea aff. ramosa Schott ex Koehne & $\mathrm{P} 28$ \\
\hline Chilicola sp. $^{\mathrm{a}}$ & B29 & Desmodium triflorum (L.) DC. & P29 \\
\hline Coelioxys simillima Smith & $\mathrm{B} 30$ & Dioclea grandiflora Mart. ex. Benth. & P30 \\
\hline Coelioxys tolteca Cresson $^{\text {a }}$ & B31 & Erythrina velutina Willd. & P31 \\
\hline Diadasina paraensis (Ducke) & B32 & Evolvulus sp.1 & P32 \\
\hline Diadasina riparia (Ducke) & B33 & Harrisia adscendens (Gurke) & P33 \\
\hline 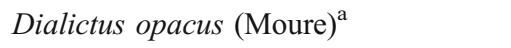 & B34 & Heliotropium angiospermum Murray & P34 \\
\hline Dialictus sp. ${ }^{\mathrm{a}}$ & B35 & Herissantia crispa (L.) Briz. & P35 \\
\hline Dichranthidium luciae Urban $^{\mathrm{a}}$ & B36 & Hyptis fruticosa Salzm. & P36 \\
\hline Epanthidium tigrinum (Schrottky) ${ }^{\mathrm{a}}$ & B37 & Inga vera Willd. & P37 \\
\hline Euglossa cordata (Linnaeus) ${ }^{\mathrm{a}}$ & B38 & Ipomoea bahiensis Willd. & P38 \\
\hline Euglossa securigera Dressler $^{\mathrm{a}}$ & B39 & Jatropha mollissima Baill. & P39 \\
\hline Eulaema nigrita Lepeletier & B40 & Lippia cf. alba (Mill.) N.E.Br. & $\mathrm{P} 40$ \\
\hline Exomalopsis analis Spinola & B41 & Lythraceae sp.1 & P41 \\
\hline Exomalopsis auropilosa Spinola & B42 & Lonchocarpus cultratus (Vell.) & P42 \\
\hline Florilegus festivus (Smith) ${ }^{\mathrm{a}}$ & B43 & Machonia spinosa & P43 \\
\hline
\end{tabular}


Table I. (continued)

\begin{tabular}{|c|c|c|c|}
\hline Bees & Code & Plants & Code \\
\hline Frieseomelitta $\mathrm{sp}$. & B44 & Malpighia emarginata DC. & P44 \\
\hline Gaesischia glabrata Urban $^{\mathrm{a}}$ & B45 & Malpighiaceae sp.1 & P45 \\
\hline Gaesischia hyptidis (Ducke) & B46 & Malvastrum tomentosum (L.) S.R. Hill & P46 \\
\hline Megachile (Acentron) sp. & B47 & Mascagnia rigida Griseb. & P47 \\
\hline Megachile (Austromegachile) sp. & B48 & Melochia tomentosa $\mathrm{L}$. & P48 \\
\hline Megachile paulistana Schrottky & B49 & Microtea maypurensis G. Don & P49 \\
\hline Megachile (Pseudocentron) sp.1 & B50 & Mimosa arenosa Poir. & P50 \\
\hline Megachile (Pseudocentron) sp.2 & B51 & Mimosa invisa Mart. & P51 \\
\hline Megachile (Pseudocentron) sp. $3^{\mathrm{a}}$ & B52 & Momordica charantia $\mathrm{L}$. & P52 \\
\hline Megachile cylindrica Friese & B53 & Ocimum americanum $\mathrm{L}$. & P53 \\
\hline Melipona asilvai Moure & B54 & Ocimum canum Sims & P54 \\
\hline Melipona quadrifasciata Lepeletier $^{\mathrm{a}}$ & B55 & Oxalis psoraleoides Mart. & P55 \\
\hline Melissodes nigroaenea Smith & B56 & Passiflora aff. violacea Vell. & P56 \\
\hline Melissoptila pubescens Smith & B57 & Peltogyne pauciflora Benth. & P57 \\
\hline Melitoma segmentaria (Fabricius) ${ }^{\mathrm{a}}$ & B58 & Petiveria alliacea $\mathrm{L}$. & P58 \\
\hline Mesoplia sp. ${ }^{\mathrm{a}}$ & B59 & Piptocarpha sp.1 & P59 \\
\hline Nomiocolletes cearensis (Ducke) ${ }^{\mathrm{a}}$ & B 60 & Piriqueta racemosa Sweet. & $\mathrm{P} 60$ \\
\hline Paratetrapedia sp. & B61 & Platymiscium floribundum Vogel & P61 \\
\hline Parepeolus aterrimus Friese $^{\mathrm{a}}$ & B62 & Polygala violacea Albl. & P62 \\
\hline Parepeolus sp. $^{\mathrm{a}}$ & B63 & Portulaca oleracea L. & P63 \\
\hline Plebeia sp. 1 & B64 & Priva bahiensis DC. & P64 \\
\hline Plebeia sp. $2^{\mathrm{a}}$ & B65 & Prosopis juliflora (Sw.) DC. & P65 \\
\hline Psaenythia variabilis Ducke ${ }^{\mathrm{a}}$ & B66 & Ptilochaeta bahiensis Turcz. & P66 \\
\hline Centris sponsa Smith $^{\mathrm{a}}$ & B67 & Rhynchosia minima (L.). DC. & P67 \\
\hline Tapinotaspoides serraticornis (Friese) & B68 & Ruellia paniculata $\mathrm{L}$. & P68 \\
\hline Tetragonisca angustula (Latreille) & B69 & Ruprechtia laxiflora Meisn. & P69 \\
\hline Triepeolus sp. ${ }^{\mathrm{a}}$ & B70 & Senna macranthera (Collad.) & $\mathrm{P} 70$ \\
\hline Trigona spinipes (Fabricius) & B71 & Senna spectabilis DC. & P71 \\
\hline Trigonisca $\mathrm{sp}$. & B72 & Sida paniculata $\mathrm{L}$. & $\mathrm{P} 72$ \\
\hline Xylocopa carbonaria Smith & B73 & Solanum paniculatum $\mathrm{L}$. & P73 \\
\hline Xylocopa cearensis Ducke & B74 & Spondias tuberosa Arruda & P74 \\
\hline Xylocopa cf. suspecta Moure \& Camargo ${ }^{a}$ & B75 & Stigmaphyllon auriculatum A. Juss. & P75 \\
\hline Xylocopa frontalis (Olivier) & B76 & Tabebuia aurea Benth. \& Hook.f. & P76 \\
\hline Xylocopa grisescens Lepeletier & B77 & Handroanthus impetiginosus (Mart. ex DC.) & P77 \\
\hline Xylocopa muscaria (Fabricius) ${ }^{\mathrm{a}}$ & B78 & Talinum patens Juss. & P78 \\
\hline Xylocopa ordinaria Smith $^{\mathrm{a}}$ & B79 & Trichilia hirta L. & P79 \\
\hline \multirow[t]{4}{*}{ Xylocopa sp. $1^{\mathrm{a}}$} & B80 & Turnera chamaedrifolie Cambess. & $\mathrm{P} 80$ \\
\hline & & Turnera sp. 1 & P81 \\
\hline & & Waltheria indica $\mathrm{L}$. & P82 \\
\hline & & Ziziphus joazeiro Mart. & P83 \\
\hline
\end{tabular}

${ }^{a}$ Bees represented by less than ten individuals and, hence, were excluded from the analysis

their temporal niches, with most bee species concentrating their activities at specific hours of the day. This means that, in extreme environments, such as the Caatinga, abiotic 
Figure 1. Number of bees species and plant species visited in the Caatinga of Castro Alves, northeastern Brazil.

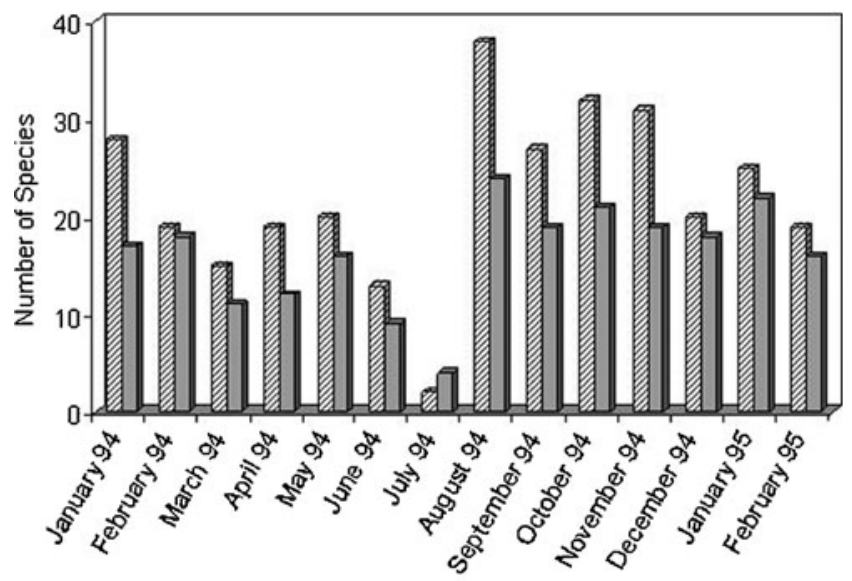

bees

口plants conditions might play an important role in structuring the community of flower-visiting bees. On the other hand, the foraging activity of some bee species may be more strongly influenced by fluctuations in the availability of food resources throughout the day (Stone et al. 1999; Gottlieb et al. 2005).

In a harsh environment such as the Caatinga, where temperature is too high and humidity is too low for bees at some hours of the day, bee species are probably hindered from segregating their foraging times since they have to concentrate their activity at milder hours. Several studies conducted in the Brazilian tropical dry forests have shown that during the dry season, the availability of food resources is very low for insects (Vasconcelos et al. 2010; Santos et al. 2010). Although 80 bees species were recorded visiting flowers of 83 plant species, on average, only 16 plant species were visited each month. In the peak of the dry season, from June to July, the number of flowering plants visited by bees was very small (ranging from four to nine plant species visited each month). The overlap between pairs of species was lower for the trophic niche $(79 \%$ of the pairs exhibiting values below $30 \%$ ) than for the temporal niche $(45 \%$ of the pairs exhibiting values above $50 \%$ ). Our results indicate that bees have developed strategies to attenuate the competition for food, thus allowing their coexistence.

Similar results have been obtained in other studies, with low trophic niche overlap (Schoener's index) among most pairs of bee species in forests (Wilms et al. 1996) and caatingas (Aguiar and Santos 2007). Therefore, species that coexist in a given locality should be more similar in some features than in others, responding to a balance between food and environmental requirements, as proposed by Liebold (1997). Our results are also consistent with Gause's (1934) principle of competitive exclusion which states that ecologically similar species that coexist in a given area must differ strongly in at least one dimension of their niches, so they do not exclude each other.

It is interesting that the results of the conventional niche analysis and of the network analysis were very similar, reinforcing our interpretations. Future studies could investigate the biological mechanisms that determine niche overlap among particular pairs of species in order to understand why some species are able to overlap their niches more strongly than others. 


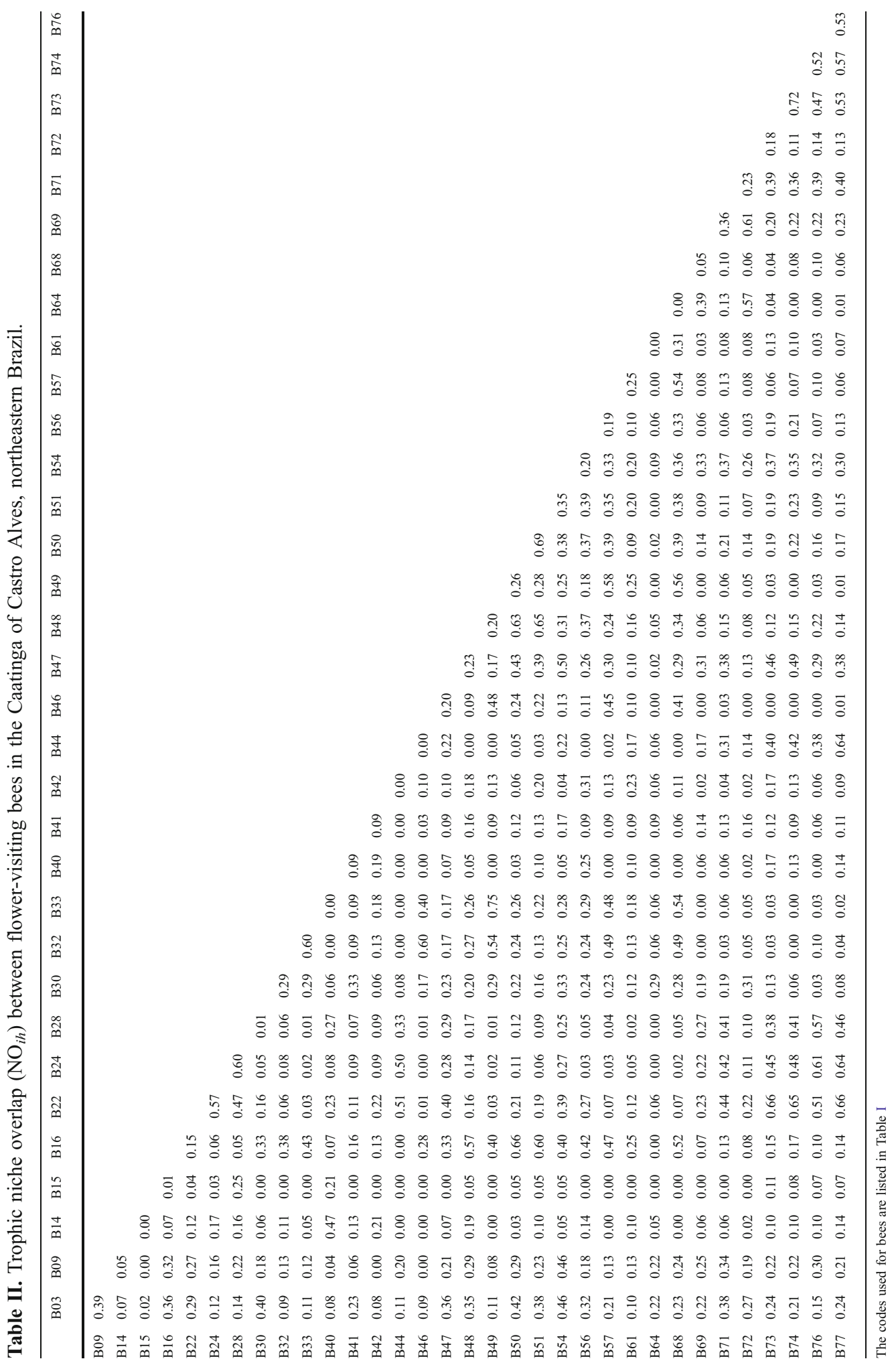




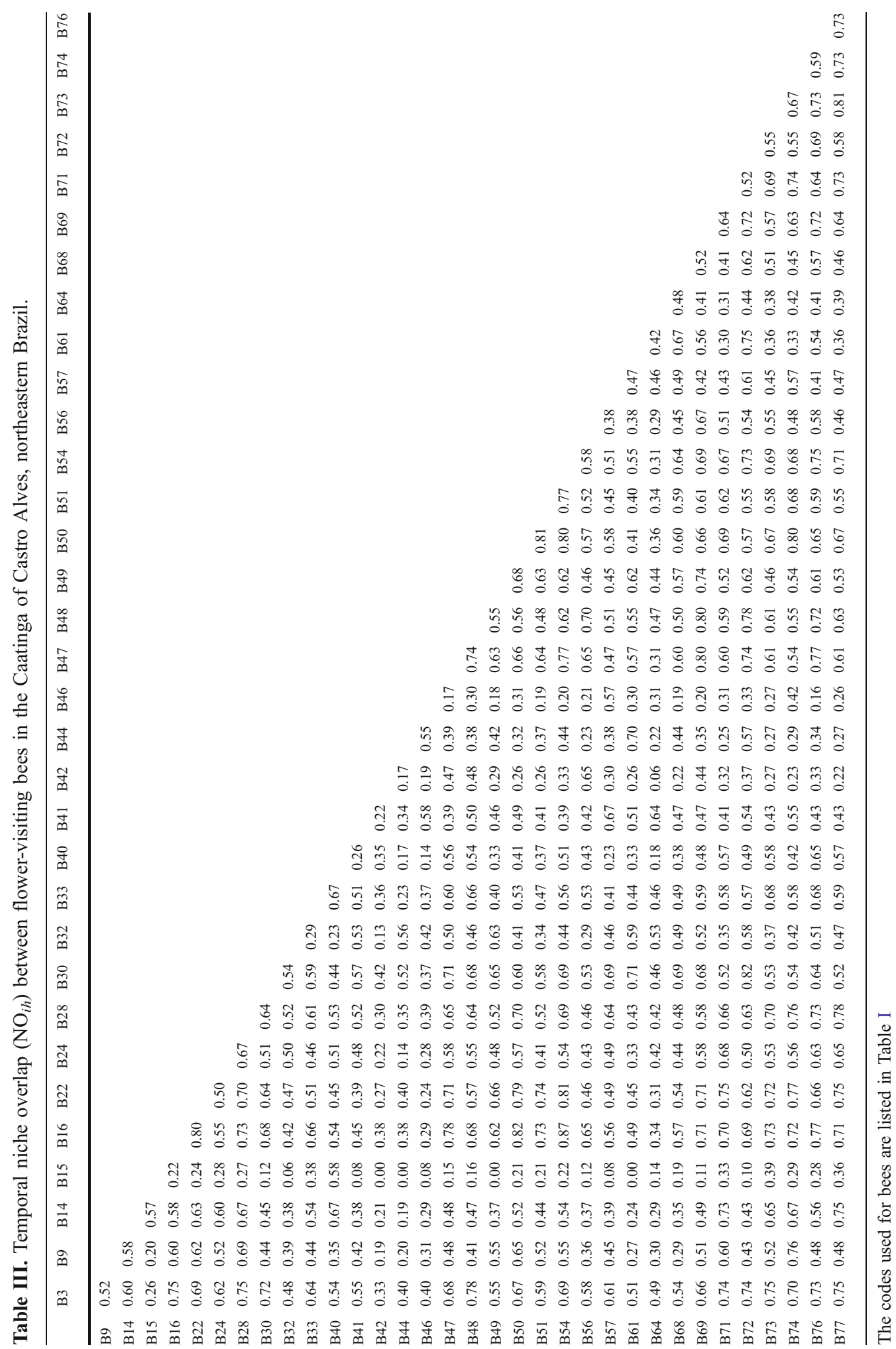


Figure 2. Flower-visiting network of bees in the Caatinga of Castro Alves, northeastern Brazil. Bees are represented as rectangles on the right-hand side and plants are represented as rectangles on the left-hand side. The thickness of each line (flower visiting interaction) is proportional to the number of bees observed visiting each plant species. The size of each rectangle is proportional to the number of visits observed for each species of bee or plant. Species codes are listed in Table I.

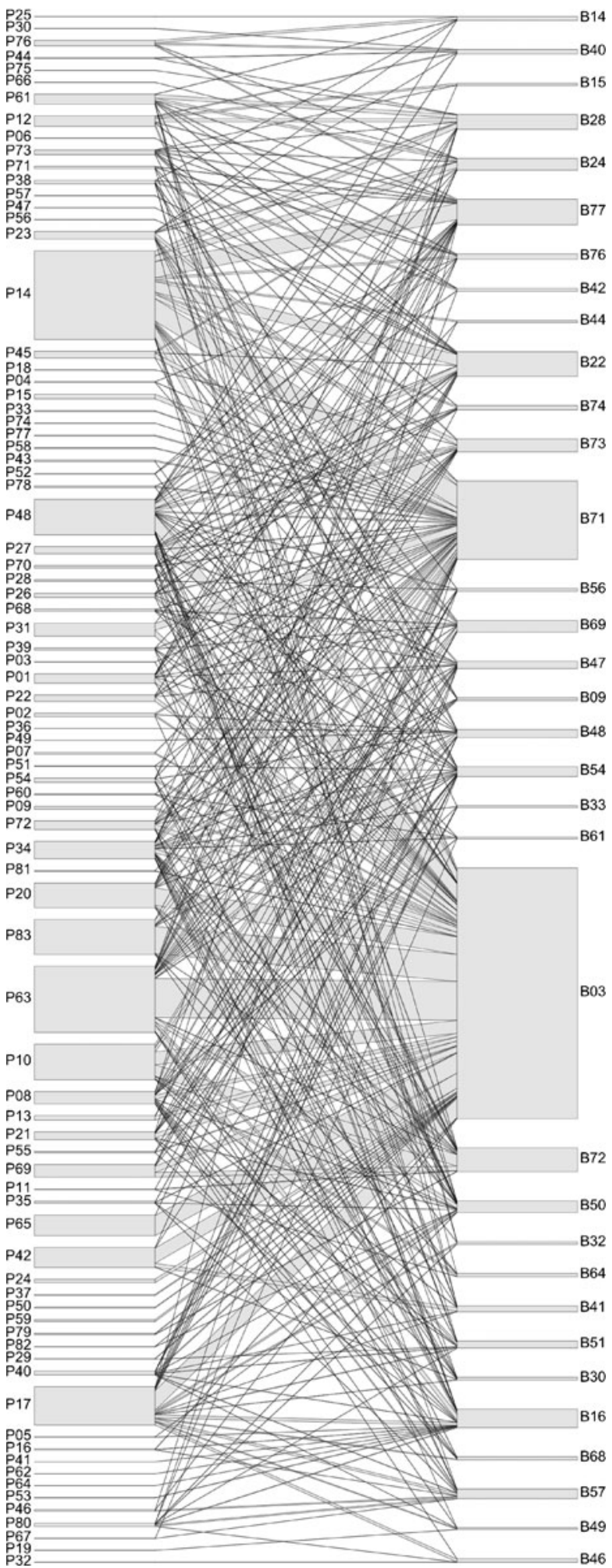


Figure 3. Foraging time network of flower-visiting bees in the Caatinga of Castro Alves, northeastern Brazil. Flowervisiting bees are represented as rectangles on the left-hand side and visit times are represented as rectangles on the right-hand side. The thickness of each line (foraging activity) is proportional to the number of bees observed foraging at each time. The size of each rectangle is proportional to the number of visits observed for each species of bee or for each time. Species codes are listed in Table I.

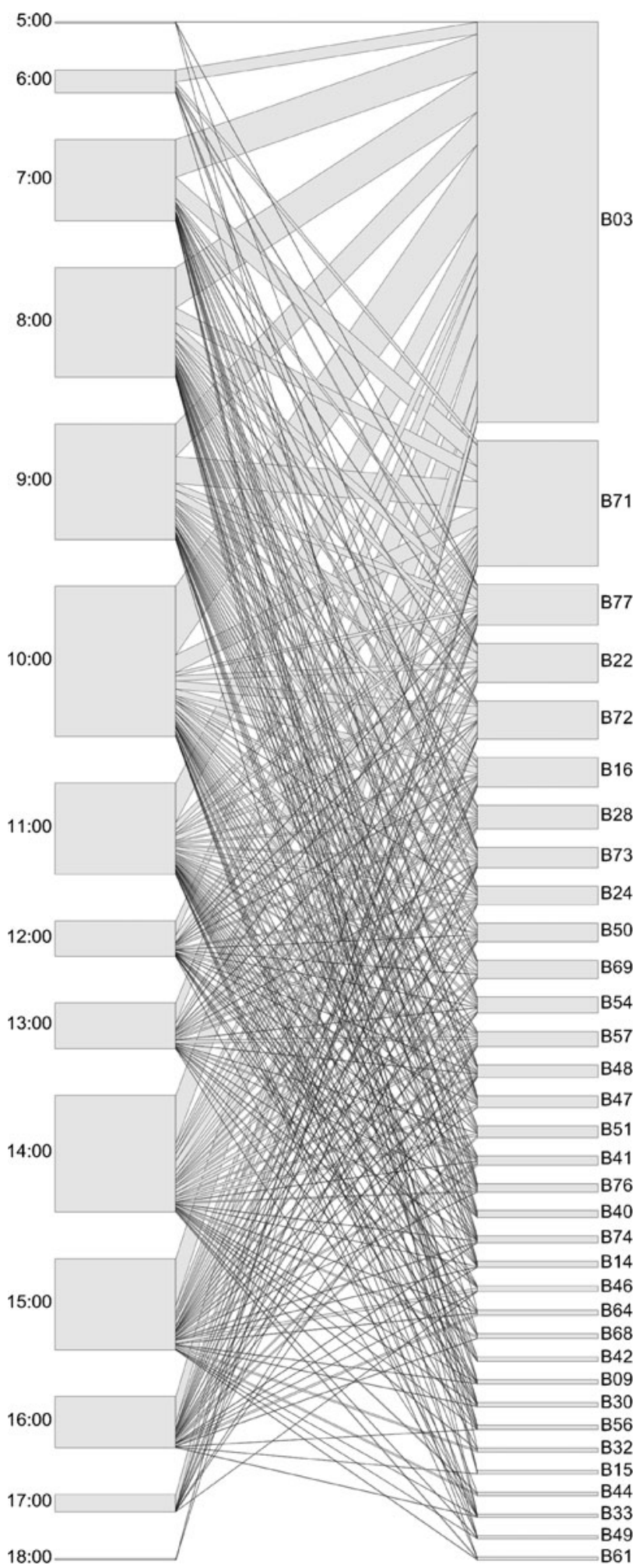




\section{ACKNOWLEDGMENTS}

We thank Dr. Luciano Paganucci de Queiroz (UEFS) who identified the plants. The Brazilian Research Council (CNPq) and the Research Foundation of Bahia (FAPESB) funded this project. CNPq granted research productivity fellowships to GMM Santos and CAL Carvalho. The Alexander von Humboldt Foundation granted a postdoctoral fellowship (no. 1134644) to MAR Mello.

Chevauchement des niches trophique et temporelle dans une guilde d'abeilles (Hymenoptera, Apoidea), visitant les fleurs d'une forêt sèche tropicale

Niche trophique/ niche temporelle/ Apoidea/ Caatinga/

Überlappung von trophischen und zeitlichen Nischen in der blütenbesuchenden Bienengilde (Hymenoptera, Apoidea) eines tropischen Trockenwalds

Trophische Nische/ zeitliche Nische/ Nischenüberlappung/Bienengilde/Apoidea

\section{REFERENCES}

Araújo, M.S., Guimarães Jr., P.R., Svanbäck, R., Pinheiro, A., Guimarães, P., Reis, S.F., Bolnick, D.I. (2008) Network analysis reveals contrasting effects of intraspecific competition on individual vs. population diets. Ecology 89, 1981-1993

Araújo, M.S., Martins, E.G., Cruz, L.D., Fernandes, F.R., Linhares, A.X., Reis, S.F., Guimaraes, P.R. (2010) Nested diets: a novel pattern of individuallevel resource use. Oikos 119, 81-88

Bascompte, J., Jordano, P. (2007) The structure of plantanimal mutualistic networks: the architecture of biodiversity. Annu. Rev. Ecol. Evol. Syst. 38, 567-593

Behmer, S.T., Joern, A. (2008) Coexisting generalist herbivores occupy unique nutritional feeding niches. Proc. Natl. Acad. Sci. U. S. A. 105, 1977-1982

Blondel, J. (2003) Guilds or functional groups: does it matter? Oikos 100, 223-231

Costa, L.F., Rodrigues, F.A., Travieso, G., Villas Boas, P.R. (2007) Characterization of complex networks: a survey of measurements. Adv. Phys. 56, 167-242

Dormann, C.F., Fründ, J., Blüthgen, N., Gruber, B. (2009) Indices, graphs and null models: analyzing bipartite ecological networks. Open Ecol. J. 2, 7-24

Feinsinger, P., Spears, E.E., Poole, R.W. (1981) A simple measure of niche breadth. Ecology 62, 27-32
Gause, G.F. (1934) The struggle for existence. Williams \& Wilkins, Baltimore

Gottlieb, D., Keasar, T., Shmida, A., Motro, U. (2005) Possible foraging benefits of bimodal daily activity in Proxylocopa olivieri (Lepeletier) (Hymenoptera: Anthophoridae). Environ. Entomol. 34, 417-424

Hairston, N.G. (1984) Inferences and experimental results in guild structure. In: Strong, D.R., Simberloff, D., Abele, L.G., Thistle, A.B. (eds.) Ecological communities: Conceptual issues and the evidence, pp. 23-27. Princeton University Press, Princeton

Hölldobler, B., Wilson, E.O. (1990) The ants. Harvard University Press, Cambridge

Liebold, M.A. (1997) Similarity and local co-existence of species in regional biotas. Evol. Ecol. 29, 95-110

Pianka, E.R. (1973) The structure of lizard communities. Annu. Rev. Ecol. Evol. Syst. 4, 53-74

Pianka, E.R. (1980) Guild structure in desert lizards. Oikos 35, 194-201

Presley, S.J., Willig, M.R., Castro-Arellano, I., Weaver, S.C. (2009) Effects of habitat conversion on temporal activity patterns of phyllostomid bats in lowland Amazonian rain forest. J. Mammal. 90, 210-221

Root, R.B. (1967) The niche exploitation pattern of the blue-gray gnatcatcher. Ecol. Monogr. 37, 317-350

Sakagami, S., Laroca, S.F., Moure, J.S. (1967) Wild bee biocenotics in São José dos Pinhais (PR), south Brazil. J. Fac. Sci., Hokkaido Univ., Ser. VI, Zoology 16, 253-291

Santos, G.M.M., Aguiar, C.M.L., Mello, M.A.R. (2010) Flower-visiting guild associated with the Caatinga flora: trophic interaction networks formed by social bees and social wasps with plants. Apidologie 41, 466-475

Schoener, T.W. (1986) Resource partitioning. In: Kikkawa, J., Anderson, D.J. (eds.) Community ecology-pattern and process, pp. 91-126. Blackwell Scientific, London

Stone, G.N., Gilbert, F., Willmer, P., Potts, S., Semida, F., Zalat, S. (1999) Windows of opportunity and the temporal structuring of foraging activity in a desert solitary bee. Ecol. Entomol. 24, 208-221

Thomson, D.M. (2006) Detecting the effects of introduced species: a case study of competition between Apis and Bombus. Oikos 114, 407-418

Vasconcellos, A., Ricardo, A., Almeida, A.M., Araujo, H.F.P., Oliveira, E.S., Oliveira, U. (2010) Seasonality of insects in the semi-arid Caatinga of northeastern Brazil. Revta. bras Ent. 54, 471-476

Willmer, P., Stone, G. (1997) Temperature and water relations in desert bees. J. Therm. Biol. 22, 453-465

Wilms, W., Imperatriz-Fonseca, V.L., Wolf, E. (1996) Resource partitioning between highly eusocial bees and possible impact of the introduced Africanized honey bee on native stingless bees in the Brazilian rain forest. Stud. Neotropical Fauna Environ. 31, 137-151 